\title{
Parental Income, Socio-Cultural, and Living Environment as Factors Causing Children to Drop Out of Middle School in Rengat Barat District
}

Desy Haryani Z*

SMP Negeri 1 Rengat Barat, Indragiri Hulu, 29351, Indonesia

\section{ARTICLE INFO}

Article history:

Received: 10 June 2021

Revised: 14 Jan 2022

Accepted: 16 Jan 2022

Published online: 24 Jan 2022

\section{Keywords:}

Parents' Income

Socio-cultural

Living Environment

Dropout

\begin{abstract}
A B S T R A C T
The analyzing whether parental income, socio-culture, and living environment are factors that cause children to drop out of school at SMP Negeri Rengat Barat District were investigated in this study. The study used a quantitative approach because the research data was in the form of numbers and the analysis uses statistics to test hypotheses. The types of data used in this study were primary data and secondary data. The data analysis technique used to solve the problem in this study was a quantitative analysis technique using the KMO test (Kaiser Meyer Olkin Measure of Sampling Adequacy) and Bartleets test of sphericity. The results showed that parents' income, sociocultural and living environment were factors that caused children to drop out of school at the State Junior High School in West Rengat District. However, the correlation value of the living environment variable is greater than the socio-cultural variables and parents' income. Thus it can be interpreted that the dominant variable affecting children dropping out of school is the environment where they live because it has the highest correlation value. Then followed by socio-cultural and finally the income of parents.
\end{abstract}

\section{Introduction}

Every human being has the right to receive or obtain education both formally, informally and non-formally, so that he will have a strong mental, moral, moral and physical and become a highly cultured human being in carrying out his duties, obligations and responsibilities in social life. This is in accordance with the mandate of the Law of the Republic of Indonesia No. 20 of 2003 Article 6 paragraph 1 which states that every citizen aged seven to fifteen years is required to attend basic education. 
From the mandate of the Law of the Republic of Indonesia No. 20 of 2003 Article 6 paragraph 1 it can be concluded that every human being in this case is a resident of school age or aged 7-15 years is required to attend a minimum education is basic education. The compulsory basic education chosen by Indonesia is 9 years, namely elementary and junior high school education. When viewed in terms of age, those who are required to attend school are those aged 7-15 years. However, in general, there are still many school-age residents in Indonesia who have not completed basic education or who are better known as dropouts.

According to Imron (2015), dropouts are dropping out of school prematurely or before graduation. According to Mudyahardjo (2016), dropping out is leaving school before completing the entire study period set by the school concerned. Dropouts are someone who has entered an institution at the elementary, junior high, and high school levels to study and receive lessons, but does not complete their education or does not graduate and then they quit or leave school. Dropouts can also be interpreted as children who are temporarily in school so they stop or do not continue their education to a higher level. According to Bagoe (2017), the types of dropouts based on Djumhur and Surya's theory are grouped into three types, including:

1. Dropping out of school or stopping at a level that occurs when a student or student quits school but is still at a certain level.

2. Dropping out at the end of a level occurs when a student stops at the end of a certain school level.

3. Dropping out or stopping between levels occurs when students continue their lessons to a higher level.

The high number of dropout students is one of the priorities that the government continues to pay attention to. Dropout is a global problem that occurs not only in developing countries such as Indonesia, but even in developed countries such as the United States and Europe. (Bonaldo 2016). Education is essentially a must for every human being as a whole. Law of the Republic of Indonesia No. 20 of 2003 article 1 states that "Education is a conscious and planned effort to create a learning atmosphere and learning process so that students actively develop their potential to have religious spiritual strength, self-control, personality, intelligence, noble character, and the skills they need., society, nation and state".

The delay in education is a matter of concern because it is not in accordance with the Law of the Republic of Indonesia No. 20 of 2003 article 3 explains the function and purpose of education. Education functions to develop capabilities and shape the character and civilization of a dignified nation in the context of educating the nation's life, aiming at developing the potential of students to become human beings who believe and are devoted to God Almighty, have noble character, are healthy, knowledgeable, capable, creative, independent and become a democratic and responsible citizen.

Education determines the quality of human resources (HR) owned by a nation. The Indonesian government in this case has made a 9-year compulsory education policy as stated in the Government Regulation of the Republic of Indonesia 
number 47 of 2008 article 9 paragraph 1. Education in Junior High Schools (SMP) directs that students are sensitive to the social environment that exists in society and have positive attitude towards the improvement of all inequality that occurs. The problem of dropout rates is one of the obstacles in the development of education. The case of children dropping out of school in Indonesia can still be said to be quite high.

The family's economic inability to pay school fees and the lack or absence of \#attention from parents to children, result in problems for education such as dropout problems. This is in accordance with the National Education System Law No. 20 of 2003 Article 7 paragraph 1 states that, "Parents of compulsory school age children are obliged to provide basic education to their children." In article 8 it is stated that, "The community is obliged to provide resource support in the implementation of education" and in article 10 it is stated that:

1. The Government and Regional Governments are obligated to provide services and facilities, as well as to ensure the implementation of quality education for every citizen without discrimination.

2. The Government and Regional Governments are obliged to guarantee the availability of funds for the implementation of education for every citizen aged seven to fifteen years. We are certainly concerned because there are still some of our brothers and sisters who do not understand how important education is today. This is known from the fact that there are still children who drop out of school due to certain things, even though the government of the Republic of Indonesia has implemented the 9-year compulsory education program for basic education.

Rengat Barat sub-district was used as a research area because there are many poor people in the area. The more poor people in the area, the greater the chance for children to drop out of school. According to Shahidul (2015) "related factors to influence children dropping out of school are social, economic, and cultural factors". According to Sugiyono (2015) economic factors, family, and peers are used as the cause of children dropping out of school. People who still have a weak economy, will prioritize meeting their basic daily needs rather than the need for education for the future of their children. Generally, they are less likely to get an affordable and decent education. Dropping out of school a child or society, is actually not desired by the people who experience it, as well as other people who see this reality firsthand.

According to the results of interviews obtained from each parent of each dropout student at the State Junior High School in West Rengat Subdistrict, some of the heads of families found that the income of the head of the family, some of whom worked as farmers, was around Rp. $900,000.00$ to Rp. 1,800,000/month, some of them have an income of Rp. 100,000/day who work as construction workers. Parents who work as farmers whose children drop out of school, have unstable incomes because they depend on the results of the harvest they get. Likewise, parents who have jobs in oil palm plantations as laborers, they have the status of being casual daily laborers which results in the income being obtained every month is also not fixed because of the daily income payment system. 
The results of the data from the research obtained as information material regarding the income of parents of dropout students are still not fixed and classified as low. And from this income, it is predicted that parents can only meet basic needs. The educational needs of their children are very difficult to fulfill. Socio-culture and living environment are predicted to have an impact on State Junior High School (SMP) children who have dropped out of school in West Rengat District. The awareness of each parent about the need for education for their children affects the continuity of their children's schooling.

From interviews, parents think that their children can read and write enough to be used as capital to earn money, so they think there is no need to continue higher education. Education is supported by the view that parents do not have to continue higher education for girls because they end up only taking care of the house later. The family environment, economic status, socio-educational status of parents affect various milestones in a child's development (Mishra, 2014). They can also find figures or role models who provide motivation to continue their education to a higher level. According to Wahab (2015) the learning environment includes:

1. Social environment

a. Community social environment

b. Family social environment

c. School social environment

2. Non-social environment

a. Natural environment

b. Instrumental environment

Setiawan (2015) argues that what is said to be dropping out of school is the condition of an individual being unable to complete education at the level he is currently carrying out due to various reasons. According to Kamsihyati (2016) dropping out of school is a predicate given to former students who are unable to complete a level of education, so they cannot continue their studies to the next level of education. Meanwhile, according to Ungureanu (2017) dropping out of school early means that the student did not complete junior high school, compulsory education and did not obtain a qualification or diploma. Dropping out early implies giving up all forms of education and refers to young people leaving school before completing compulsory education; completed compulsory schooling but did not get a qualification after high school; attend professional training courses without attaining an equivalent qualification at upper secondary level.

Lockett (2015) in his research suggests that the main factor for students dropping out of school is the self-perception that they feel backward or often fail in carrying out their duties. While external factors include: the state of the family's economic status, parental attention and parental relationships that are less harmonious. Several studies have discussed that parents' income is the most dominant factor causing children to drop out of school, however, socio-cultural factors and distance from home to school are also the causes of dropping out. (Zainuri 2014; Baningsih 2020; Mahmuddin 2019; Mua 2017). Soares (2015) adds that different 
wishes from parents and perceptions of job opportunities after the study is completed are factors that influence school dropouts.

The objectives of this research are as follows:

a. This study aims to determine the income of parents as a factor that causes children to drop out of school at the State Junior High School in West Rengat District.

b. This study aims to determine the socio-cultural factors that cause children to drop out of school at the State Junior High School in West Rengat District.

c. This study aims to determine the living environment as a factor that causes children to drop out of school in SMP Negeri Rengat Barat District.

d. This study aims to determine the most dominant factor that causes children to drop out of school in SMP Negeri Rengat Barat District.

\section{Methodology}

This study used a quantitative approach and analysis used statistics to test hypotheses (Sugiyono, 2015). The population in the study was the total number of dropouts from State Junior High Schools from 5 schools in West Rengat District. The sampling method used the Saturated Sampling Technique. According to Sugiyono (2015), that: "saturated sampling technique is a sampling technique when all members of the population are used as samples." This is because the population used in this study is relatively small, less than 30 people. The population as well as the sample in this study amounted to 26 people. Collecting data in this study used the method of documentation, interviews and questionnaires.

\section{Results and Discussion}

In this study, the factors that are predicted to cause children to drop out of school are parents' income, socio-cultural and living environment. From these results, it is known that the living environment variable is the most dominant factor in children dropping out of school. The number of siblings in the family can affect the distribution of resources available for education among children. The number of siblings can reduce a child's school participation rate. This can be because the time and resources for each child will decrease when the number of children owned is more (Fahmi, 2014). The occupations of the people in rural areas are generally farmers. This will greatly affect the parental paradigm about the importance of education. In this case, parents still think that education is not too important, the most important thing now is how to meet the daily needs of the family so that their children are more important to work to help their parents (Aristin, 2015). 


\section{a. KMO Test and Bartleet's Test of Sphericity}

A variable is said to be forming a factor if the KMO and Barlette's numbers obtained are above 0.5 and the probability value (sig) is smaller than 0.05 , which means the research variables can be analyzed further. And from the test, the results are obtained in Table 1.

Table 1. Results of KMO and Barlette's Test

\begin{tabular}{lll}
\hline Kaiser-Meyer-Olkin Measure of Sampling Adequacy. & .670 \\
Bartlett's Test of Sphericity & Approx. Chi-Square & 17.737 \\
& Df & 3 \\
& Sig. & .000 \\
\hline
\end{tabular}

Source: Research Results, 2021

From Table 1 above, it is known that the KMO and Barlett test scores are 0.670 with a significance value of 0.000 . Because the KMO number is above 0.5 and the significance is far below 0.05 , the variables and samples used are feasible to be analyzed using factor analysis.

\section{b. Test Measure of Sampling Adequacy (MSA)}

The MSA number criteria range from 0 to 1 , where the variable can be predicted and can be analyzed further if the MSA number is $>0.5$. And from the tests carried out, the results are obtained in Table 2.

Table 2. MSA (Measure of Sampling Adequacy) Test Results

\begin{tabular}{lllll}
\hline & \multicolumn{3}{c}{ Anti-image Matrices } & Living \\
& & Parents' Income & Socio-cultural & Environment \\
\hline Anti-image & Parents' Income & .744 & -.158 & -.172 \\
Covariance & & & \\
& Socio-cultural & -.158 & .589 & -.300 \\
& Living Environment & -.172 & -.300 & .582 \\
Anti-image & Parents' Income & $.767 \mathrm{a}$ & -.238 & -.261 \\
Correlation & & & & \\
& Socio-cultural & -.238 & $.644 \mathrm{a}$ & -.512 \\
& Living Environment & -.261 & -.512 & $.639 \mathrm{a}$ \\
\hline a. Measures of Sampling Adequacy(MSA) & & \\
\hline
\end{tabular}

Source: Research Results, 2021

From Table 2 above, it is known that all variables get MSA values above 0.5 $(0.767 ; 0.644$ and $0.639>0.05)$. Thus it can be interpreted that the research variables deserve to be analyzed further. 


\section{c. Factoring or extraction}

Before doing factoring or extraction, observations were made on the value of the communality of the variables formed. The requirement for communalities value itself is greater than 0.5. From the tests carried out, the results obtained in table 3 .

Table 3. Communalities Test Results

\begin{tabular}{lll}
\hline & Communalities & \\
& Initial & Extraction \\
\hline Parents' Income & 1.000 & .574 \\
Socio-cultural & 1.000 & .717 \\
Living Environment & 1.000 & .726 \\
Extraction Method: Principal Component Analysis. & \\
\hline
\end{tabular}

Source: Research Results, 2021

From Table 3 above, the communalities values of the three variables above are 0.5 so that all these variables can be tested using further factor analysis. Furthermore, based on the table above, we can know that the value for the parent's income variable is 0.574 , which means that $57.4 \%$ of the variation in the amount of the parent's income variable can be explained by the formed factors. The next process of factor analysis is testing the total variance explained. The number of eigenvalues is always sorted from the largest to the smallest value. From the tests carried out, the results are obtained in Table 4.

Table 4. Total Variance Explained . Test Results

\begin{tabular}{|c|c|c|c|c|c|c|}
\hline \multicolumn{7}{|c|}{ Total Variance Explained } \\
\hline \multirow[b]{4}{*}{ Component } & & & & Extraction & Sums & Squared \\
\hline & \multicolumn{2}{|c|}{ Initial Eigenvalues } & \multirow{3}{*}{ ofCumulative } & Loadings & & \\
\hline & & $\%$ & & \multirow{2}{*}{\multicolumn{2}{|c|}{$\begin{array}{ll} & \% \\
\text { Total } & \text { Variance }\end{array}$}} & \multirow{2}{*}{$\begin{array}{l}\text { ofCumulative } \\
\%\end{array}$} \\
\hline & Total & Variance & & & & \\
\hline 1 & 2.017 & 67.248 & 67.248 & 2.017 & 67.248 & 67.248 \\
\hline 2 & .595 & 19.847 & 87.095 & & & \\
\hline 3 & .387 & 12.905 & 100.000 & & & \\
\hline Extraction $\mathrm{N}$ & hod: $\mathrm{P}$ & ipal Compc & nent Analysis. & & & \\
\hline
\end{tabular}

Source: Research Results, 2021

From Table 4 above, it is known that the results of the extraction using PCA show that the number of variables that have been extracted are 3 variables, and the factor formed is only 1 factor which is indicated by the eigenvalue $(2.017)>1$. The eigenvalue $<1$ then cannot be used as a factor. a variable because it is considered to have no correlation with the factors formed. Based on these provisions, there is only one main component, so that the main component is the best summary of information from a number of items analyzed. And it is known that $67.248 \%$ of school dropouts are caused by the only factor formed in this study. 


\section{d. Component Matrix}

Component matrix aims to determine the dominant items in each component. The component matrix consists of the initial items against the formed factors. By looking at the weighting factor, it can be determined which item belongs to which factor by looking at the magnitude of the weighting factor for each item against the matrix of the formed factors. However, in this study there is only one forming factor. From the tests carried out, the results are obtained in Table 5.

Table 5. Total Variance Explained Test Results

\begin{tabular}{ll}
\hline \multicolumn{2}{c}{ Component Matrixa } \\
\cline { 2 - 2 } Component \\
\cline { 2 - 2 } Parents' Income & 1 \\
Socio-cultural & .758 \\
Living Environment & .847 \\
Extraction Method: Principal Component Analysis. & .852 \\
a. 1 components extracted. & \\
\hline
\end{tabular}

Source: Research Results, 2021

From Table 5 above, it is known that there is only one component of the matrix which is then named, where the name of the factor depends on the variables that make it up. From these results, it is known that the correlation value of the parental income variable is 0.758 ; the socio-cultural variable is 0.847 and the living environment variable is 0.852 . Thus it can be interpreted that the most dominant variable affecting children dropping out of school is the neighborhood because it has the highest correlation value. Then followed by socio-cultural and finally the income of parents.

\section{Conclusion}

Based on the results of the research and analysis of the results that have been described previously, it can be concluded that external factors consisting of parents' income, socio-cultural and living environment are the factors that cause children to drop out of school in SMP Negeri Rengat Barat District with a cumulative percentage of $67.248 \%$. Of the three variables, the living environment is the most dominant variable causing children to drop out of school.

\section{References}

Aristin, N. F. (2015). Faktor- Faktor yang Berpengaruh terhadap Anak Putus Sekolah Tingkat Sekolah Menengah Pertama (SMP) di Kecamatan Bondowoso. Jurnal Pendidikan Geografi. 20(1).

Bagoe, R. (2013). Faktor-Faktor Penyebab Anak Putus Sekolah di Desa Suka Damai Kecamatan Bulango Utara Kabupaten Bone Bolango. Skripsi, 1(221408062). 
Baningsih, N., \& Nuranisa, D. W. (2020). Analisis Penyebab Anak Putus Sekolah di Desa Sri Agung Kecamatan Banyuasin II Ditinjau Secara Geografis. Jurnal Swarnabhumi Vol, 5(1).

Bonaldo, L., \& Pereira, L. N. (2016). Dropout: Demographic profile of Brazilian university students. Procedia-Social and behavioral sciences, 228, 138143.

Fahmi, M., \& Marizkaa, D. (2014). Analisis Karakteristik Anak Tidak Bersekolah di Indonesia. Characteristics Analysis of Out of School Children in Indonesia. Jurnal Ekonomi dan Pembangunan Indonesa. 14(2).

Imron, A. (2015). Manajemen Peserta Didik Berbasis Sekolah. Jakarta: Bumi Aksara.

Kamsihyati, S., Sutomo, S., \& Suwarno, S. (2017). Kajian faktor-faktor penyebab anak putus sekolah di Desa Jangrana Kecamatan Kesugihan Kabupaten Cilacap. Geo Edukasi, 5(1).

Lockett, C., \& Cornelious, L. (2015). Factors Contributing to Secondary School Dropouts in an Urban School District. Journal Research in Higer Education, 29.

Mahmuddin, M., Halimah, S., \& Wardania, W. (2019). Penyebab Anak Putus Sekolah di Desa Tumbang Kaminting Kecamatan Bukit Santuai. Jurnal Paedagogie Media Kependidikan, Keilmuan dan Keagamaan, 7(1), 25-30.

Mishra, P. J., \& Azeez, A. (2014). Family Etiology of School Dropouts: A Psychosocial Study. International Journal of Multidisciplinary Approach and Studies, 1(5), 136-146.

Mua, V. B., \& Manginsela, E. P. (2017). Faktor-Faktor Penyebab Putus Sekolah Dari Anak Petani Dan Non-Petani Di Desa Sea Dan Desa Warembungan Kecamatan Pineleng Kabupaten Minahasa. Agri-Sosioekonomi, 13(3A), 313-322.

Mudyahardjo, R. (2016). Pengantar Pendidikan. PT Grafindo. Jakarta.

Peraturan Pemerintah Republik Indonesia Nomor 47 Tahun 2008 Tentang Wajib Belajar. Jakarta: Mendiknas.

Setiawan, R., Hasyim, A., \& Yanzi, H. (2013). Faktor-faktor yang Menyebabkan Remaja Desa Tidak Melanjutkan Pendidikan Kejenjang Sekolah Lanjutan. Jurnal Kultur Demokrasi, 2(2).

Shahidul, S. M., \& Karim, A. H. M. Z. (2015). Factors Contributing to School Dropout Among The Girls: A Review Of Literature. European Journal of research and reflection in educational sciences, 3(2).

Soares, T. M., Fernandes, N. D. S., Nóbrega, M. C., \& Nicolella, A. C. (2015). Factors Associated with Dropout Rates in Public Secondary Education in Minas Geraisl. Educação e Pesquisa, 41, 757-772.

Sugiyono. (2015). Metode penelitian Kuantitatif, kualitatif dan kombinasi (Mixed Metode), Bandung: Alfabeta.

Undang-Undang Republik Indonesia No. 20 Tahun 2003 Tentang Sisdiknas. Bandung: Citra Umbara, 2006.

Ungureanu, R. (2017). School Dropouts - A Theoretical Framework. International Journal of research in engineering and social sciences, 7(1), 21-27.

Wahab, R. (2015). Psikologi Belajar. Jakarta: Rajawali Pers.

Zainuri, M., Matsum, J. H., \& Thomas, Y. (2014). Tingkat Pendapatan, Sosial 
Budaya dan Jarak Rumah dengan Sekolah sebagai Faktor Penyebab Anak Putus Sekolah di SMPN. Jurnal Pendidikan dan Pembelajaran Khatulistiwa, 3(10).

How to cite this article:

Haryani, D. (2022). Parental Income, Socio-Cultural, and Living Environment as Factors Causing Children to Drop Out of Middle School in Rengat Barat District. Journal of Educational Sciences, 6(1), 56-65. 